\title{
Seed Pathology
}

VOLUME I 


\title{
Seed Pathology
}

\section{VOLUME I}

\author{
PAUL NEERGAARD
}

Director, Danish Government Institute of Seed Pathology for Developing Countries, Copenhagen, Denmark

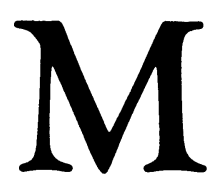


(C) Paul Neergaard 1977

Softcover reprint of the hardcover 1st edition 1977 978-0-333-19273-3

All rights reserved. No part of this publication may be reproduced or transmitted, in any form or by any means, without permission

First published 1977 by THE MACMILLAN PRESS LTD

London and Basingstoke

Associated companies in New York Dublin

Melbourne Johannesburg and Madras

ISBN 978-1-349-02844-3 ISBN 978-1-349-02842-9 (eBook)

DOI 10.1007/978-1-349-02842-9

This book is sold subject to the standard conditions of the Net Book Agreement 


\section{CONTENTS OF VOLUME I}

PREFACE Xix

SOME SUGGESTIONS ON THE USE OF THE BOOK Xxii

PART I PATHOGENS-DISEASES-HOSTS

1. Economic Significance of Seed-borne Diseases 3

1.1 DEFINITIONS 3

1.2 CROP LOSSES CAUSED BY SEED-BORNE DISEASES

1.3 SIGNIFICANCE OF SEED TRANSMISSION COMPARED WITH OTHER MEANS OF TRANSMISSION

1.4 SIGNIFICANCE OF SEED TRANSMISSION IN SELECTION OF VIRULENT PATHOGENS

2. Diseases and Injuries of Seed 40

$\begin{array}{lll}2.1 & \text { DEFINITIONS } & 40\end{array}$

2.2 PHYSIOGENIC SEED DISEASES 41

2.3 SEED DISEASES CAUSED BY VIRUSES 49

2.4 SEED DISEASES CAUSED BY BACTERIA 52

2.5 SEED DISEASES CAUSED BY FUNGI 53

2.6 SEED DISEASES CAUSED BY NEMATODES 60

2.7 EFFECTS OF AGEING IN SEEDS 61

2.8 SEED DISORDERS DUE TO UNKNOWN FACTORS 61 
2.9 MECHANICAL INJURIES IN SEEDS

2.10. CONGENITAL DISORDERS

2.11 INSECT INJURIES 66

3. Seed-borne Viruses

3.1 FACTORS PREVENTING PASSAGE OF VIRUS THROUGH SEEDS

3.2 OTHER MEANS OF TRANSMISSION

3.3 CLASSIFICATION AND NOMENCLATURE OF PLANT VIRUSES

3.4 SURVEY OF SEED-BORNE VIRUSES

3.5 SEED TRANSMISSION OF BACTERIOPHAGES

3.6 SEED TRANSMISSION OF MYCOPLASMAS

4. Seed-borne Bacteria

4.1 CLASSIFICATION

4.2 SURVEY OF SEED-BORNE BACTERIA

5. Seed-borne Fungi

5.1 FACTORS LIMITING SEED TRANSMISSION OF FUNGI

5.2 IMPACT OF CLIMATE ON DISTRIBUTION OF SEED-BORNE FUNGI

5.3 SURVEY OF SEED-BORNE FUNGI

6. Seed-borne Nematodes 
7. Storage Fungi

7.1 IMPORTANCE 282

$\begin{array}{lll}7.2 & \text { FUNGI INVOLVED } & 282\end{array}$

$\begin{array}{lll}7.3 & \text { PREDISPOSING CONDITIONS } & 285\end{array}$

7.4 CONDITIONS DURING STORAGE IN RELATION TO DEVELOPMENT OF DAMAGE

7.5 HARMFUL EFFECTS

7.6 PRECAUTIONS

8. Impact of Seed-borne and Storage Fungi on Animal and Human Health

8.1 CONDITIONS AND CASES 298

8.2 ALLERGIC DISEASES 298

$\begin{array}{lll}\text { 8.3 MYCOTOXICOSES } & 299\end{array}$

$\begin{array}{lll}8.4 & \text { MYCOSES } & 304\end{array}$

9. Types of Host in Relation to Types of Pathogen 308

$\begin{array}{ll}\text { INTRODUCTION } & 308\end{array}$

$\begin{array}{lll}9.1 & \text { GRAMINEAE } & 309\end{array}$

$\begin{array}{lll}9.2 & \text { LEGUMINOSAE } & 315\end{array}$

9.3 OTHER PLANT FAMILIES 318

10. Morphology and Anatomy of Seeds in Relation to Transmission of Pathogens

10.1 FRUIT STRUCTURES AND BRACT ENVELOPES AS MICROENVIRONMENT OF DEVELOPING SEEDS

10.2 EMBRYOLOGY AND DEVELOPMENT OF SEED STRUCTURES 
10.3 GROSS ARCHITECTURE OF SEED STRUCTURES

10.4 VASCULAR CONNECTIONS BETWEEN MOTHER PLANT AND SEED

10.5 STRUCTURE OF PROTECTING LAYERS IN SEED

\section{PART II MECHANISMS OF SEED TRANSMISSION}

Introduction to Part II

11. Environment and Plant-Seed Transmission

INTRODUCTION

11.1 STANDARD TERMINOLOGY OF GROWTH STAGES

11.2 TIME OF INFECTION AND GROWTH STAGE OF HOST

11.3 TIME OF INFECTION AND WEATHER CONDITIONS

11.4 TIME OF INFECTION AND FLOWERING PERIOD OF HOST

11.5 TIME OF INFECTION AND LOCALISATION IN SEED

11.6 TIME OF INFECTION AND SEED-BORNE FUNGUS FLORA

11.7 TIME OF INFECTION AND SEED TRANSMISSION OF VIRUSES

11.8 INFECTION OR CONTAMINATION DURING HARVEST

12. Entry Points of Seed Infection 
Contents of Volume I

12.1 INFECTION DIRECTLY FROM THE MOTHER PLANT

12.2 INFECTION FROM OUTSIDE

13. Infected or Contaminated Parts of the Seed

INTRODUCTION

13.1 OVULE INFECTION 386

$\begin{array}{lll}13.2 & \text { EMBRYO INFECTION } & 389\end{array}$

$\begin{array}{lll}13.3 & \text { ENDOSPERM INFECTION } & 394\end{array}$

13.4 SEED COAT INFECTION 396

13.5 PERICARP INFECTION 401

13.6 CONTAMINATION OF SEED COAT AND PERICARP 405

$\begin{array}{lll}13.7 & \text { BRACT INFECTION } & 407\end{array}$

13.8 CONCOMITANT SEED CONTAMINATION 407

14. Seed-Plant Transmission, Establishment of Infection and Course of Disease

INTRODUCTION

14.1 INTRAEMBRYAL INFECTION FOLLOWED BY SYSTEMIC INFECTION

14.2 INTRAEMBRYAL INFECTION FOLLOWED BY LOCAL INFECTIONS

14.3 EXTRAEMBRYAL INFECTION FOLLOWED BY SYSTEMIC INFECTION

14.4 EXTRAEMBRYAL INFECTION FOLLOWED BY LOCAL INFECTIONS 
14.5 SEED CONTAMINATION FOLLOWED BY SYSTEMIC INFECTION

14.6 SEED CONTAMINATION FOLLOWED BY EXTRAMATRICAL SAPROPHYTISM OR A DORMANT STAGE AND SUBSEQUENTLY BY LOCAL INFECTIONS

14.7 SEED CONTAMINATION FOLLOWED BY EXTRAMATRICAL SAPROPHYTISM AND SUBSEQUENTLY BY SYSTEMIC INFECTION

14.8 SEED CONTAMINATION BY STRUCTURES FROM ORGANSPECIFIC SEED INFECTION FOLLOWED BY AN EXTRAMATRICAL NON-PARASITIC PHASE AND LATER BY DIRECT ORGANSPECIFIC SEED INFECTION

15. Environmental Physicochemical Factors Affecting Establishment and Course of Disease

INTRODUCTION

15.1 INFLUENCE OF PHYSICOCHEMICAL FACTORS ON THE PREDISPOSITION OF THE HOST

15.2 INFLUENCE OF PHYSICOCHEMICAL FACTORS ON THE COURSE OF DISEASE

16. Environmental Biotic Factors Affecting Establishment and Course of Disease

INTRODUCTION

16.1 RELATIONSHIPS BETWEEN INSECTS AND BACTERIA

16.2 RELATIONSHIPS BETWEEN INSECTS AND FUNGI

16.3 RELATIONSHIPS BETWEEN INSECTS AND VIRUSES

16.4 RELATIONSHIPS BETWEEN INSECTS AND NEMATODES 
16.5 RELATIONSHIPS BETWEEN MITES AND

BACTERIA

16.6 RELATIONSHIPS BETWEEN NEMATODES AND BACTERIA

16.7 RELATIONSHIPS BETWEEN NEMATODES AND FUNGI

16.8 RELATIONSHIPS BETWEEN NEMATODES AND VIRUSES

16.9 RELATIONSHIPS BETWEEN FUNGI

16.10 RELATIONSHIPS BETWEEN BACTERIA AND FUNGI

16.11 RELATIONSHIPS BETWEEN BACTERIA

16.12 RELATIONSHIPS BETWEEN BACTERIOPHAGES AND BACTERIA

16.13 RELATIONSHIPS BETWEEN BACTERIA AND VIRUSES

16.14 RELATIONSHIPS BETWEEN VIRUSES AND FUNGI

16.15 RELATIONSHIPS BETWEEN VIRUSES

Intermezzo: Integration of Disease Disposing Factors

17. Factors Inherent in the Pathogen Affecting Establishment and Course of Disease

INTRODUCTION

17.1 PATHOGENICITY AS RELATED TO ONTOGENESIS OF THE PATHOGEN

17.2 DIFFERENTIATION OF THE PATHOGEN INTO PATHOGENIC RACES (PATHOTYPES)

17.3 INOCULUM POTENTIAL 
17.4 CONDITION OF INOCULUM 494

17.5 GENETIC IMPLICATIONS OF PATHOGENICITY 495

17.6 PHYSIOLOGIC IMPLICATIONS OF PATHOGENICITY

18. Factors Inherent in the Host Affecting Establishment and Course of Disease

INTRODUCTION (RESISTANCE AND TOLERANCE)

18.1 SUSCEPTIBILITY AND RESISTANCE AS RELATED TO ONTOGENESIS OF THE HOST

18.2 MORPHOLOGICAL IMPLICATIONS OF SUSCEPTIBILITY AND RESISTANCE

18.3 PHYSIOLOGICAL IMPLICATIONS OF SUSCEPTIBILITY AND RESISTANCE

18.4 GENETIC IMPLICATIONS OF SUSCEPTIBILITY AND RESISTANCE

18.5 EPIDEMIOLOGICAL IMPLICATIONS OF SUSCEPTIBILITY AND RESISTANCE

\section{PART III PRINCIPLES OF CONTROL}

Introduction to Part III

19. Seed Crop Management

19.1 LOCATION OF SEED PRODUCTION

19.2 CROPPING

19.3 SELECTION OF CULTIVARS

19.4 REDUCTION OR ELIMINATION OF SEED-BORNE INOCULUM 
19.5 REDUCTION OF SOIL-BORNE INOCULUM 543

19.6 ADJUSTMENT OF CULTURAL PRACTICES 545

19.7 CHEMICAL PROTECTION OF SEED CROPS 560

19.8 PROTECTIVE INOCULATION 568

19.9 PRECAUTIONS TO BE TAKEN AT HARVESTING AND PROCESSING OF THE SEED

20. Management of Seed Storage

20.1 STORAGE CONDITIONS AND MOISTURE CONTENT OF SEED

20.2 INACTIVATION OF INOCULUM BY AGEING DURING STORAGE

21. Seed Treatment, Procedures and Equipment

21.1 DEVELOPMENT OF CHEMICAL TREATMENT 595

21.2 AIMS AND REQUIREMENTS 598

21.3 TYPES OF SEED TREATMENT PROCEDURES 598

21.4 SEED TREATMENT EQUIPMENT 601

21.5 CATEGORIES OF SEED TREATMENT CHEMICALS 613

22. Mechanism and Practical Use of Chemical Seed Treatment 622 $\begin{array}{ll}\text { INTRODUCTION } & 622\end{array}$

22.1 PRE-SOWING ACTION OF GERMICIDES 623

22.2 POST-SOWING ACTION OF GERMICIDES 637

22.3 SEED TREATMENT AND TYPE OF HOST 639

22.4 SEED TREATMENT AND PHYTOTOXICITY 640 
22.5 SEED TREATMENT AND TYPE AND AMOUNT OF INOCULUM

22.6 SEED TREATMENT AND VARIABILITY OF PATHOGEN

22.7 SEED TREATMENT AND CONDITION OF THE SEED

22.8 STORAGE OF TREATED SEED

22.9 SEED TREATMENT AND FIELD CONDITIONS

22.10 PRACTICAL USE OF SEED PESTICIDES

23. Testing Seed Germicides and Treated Seed

23.1 DEFINITION AND INTERPRETATION OF GERMICIDAL EFFECT

23.2 LABORATORY TESTING

23.3 FIELD TESTING

24. Quarantine for Seed

681

INTRODUCTION

24.1 INTERNATIONAL SPREAD OF SEED-BORNE DISEASES DUE TO EXPORT AND IMPORT OF SEED

24.2 INTERCEPTION OF SEED-BORNE DISEASES

24.3 PRINCIPLES OF SETTING UP QUARANTINE REGULATIONS

24.4 PRINCIPLES OF APPLYING QUARANTINE METHODS 
APPENDIX I. REGIONAL PLANT PROTECTION

ORGANISATIONS

APPENDIX II. INTERNATIONAL CERTIFICATES

APPLICABLE FOR CERTIFICATION OF THE HEALTH

CONDITION OF SEED

\section{PART IV SEED HEALTH TESTING METHODS}

25. Objectives of Seed Health Tests

25.1 BASIC REQUIREMENTS

25.2 OBJECTIVES OF SEED HEALTH TESTS

25.3 EQUIPMENT

26. Sampling

722

27. Examination of Ungerminated Seed

728

27.1 INSPECTION OF DRY SEED

27.2 EXAMINATION OF SUSPENSIONS OBTAINED FROM WASHINGS OF SEED

27.3 EXAMINATION AFTER WASHING OF SEED, AND SEDIMENTATION

27.4 THE WHOLE EMBRYO COUNT METHOD

28. Incubation Tests I: Procedures

28.1 THE BLOTTER TEST

28.2 THE AGAR PLATE TEST - EXAMINATION OF COLONIES DEVELOPED FROM SEEDS PLATED ON AGAR MEDIA

28.4 THE WATER AGAR PLATE METHOD FOR DETECTION OF BACTERIA 
28.5 SEEDLING SYMPTOM TESTS

29. Incubation Tests II: Factors Affecting Test Results

29.1 SELECTION OF TEST TYPE

29.2 FACTORS INVOLVED IN THE CONDITION OF SEED

29.3 AMOUNT OF INOCULUM PER SEED, AND THE FACTOR OF ONSET

29.4 RESPONSE OF PATHOGEN TO TEST CONDITIONS

29.5 FACTORS OF VARIATION IN INCUBATION TESTS 763

30. Bioassays and Biochemical Procedures

30.1 INDICATOR TEST - THE INOCULATION METHOD 789

30.2 THE PHAGE-PLAQUE METHOD

30.3 SEROLOGICAL METHODS

31. Inspection of Plants beyond the Seedling Stage

31.1 GROWING-ON TEST PROCEDURES

31.2 FIELD TRIALS

800

31.3 INSPECTION OF SEED CROPS

802

\section{PART V ASSESSMENT OF SEED-BORNE INOCULUM}

32. Forecasting Losses from Seed-borne Diseases and Assessing Disease Tolerances for Seed Health Testing

32.1 MEASURING SEED-BORNE INOCULUM POTENTIAL 
Contents of Volume I

xvii

32.2 EXTENT OF TRANSMISSION FROM SEED TO CROP - EPIDEMIOLOGICAL RATES

32.3 RELATIVE IMPORTANCE OF OTHER MEANS OF TRANSMISSION

32.4 EXTENT AND INTENSITY OF DISEASE IN THE CROP

32.5 SEED-BORNE INOCULUM IN RELATION TO YIELD REDUCTION AND CROP LOSSES

32.6 DISEASE TOLERANCE IN SEED HEALTH TESTING, AND CROP LOSSES

\title{
Contents of Volume II
}

\author{
Glossary \\ References \\ Index
}




\section{Preface}

This book has a dual purpose. On the one hand it is intended as a textbook covering the principles of seed pathology, for use in university courses at different levels. On the other, the intention is to provide a comprehensive reference book on seed-borne diseases, their detection, evaluation and control, for established workers in the following fields: university teaching and research; research at experimental stations; practical seed testing; formulation of quarantine regulations; techniques of quarantine inspection; development and testing of seed-treatment materials and procedures in laboratory and field; seed certification schemes; seed production; and the seed trade.

For some years I have taught seed pathology to students at the graduate, post-graduate and post-doctoral levels. For these courses I have used draft texts of this book. At the Danish Government Institute of Seed Pathology for Developing Countries in Copenhagen, I have had the very great privilege of co-operating with colleagues in developing countries, and I feel that this continuous contact with the problems and the potentials of the 'third world' has been most beneficial in my endeavours to outline the principles, as well as the leading philosophies, of this new branch of plant pathology and seed technology.

Nevertheless, my thoughts also go to my colleagues in the 'old world', in particular to those with whom I have co-operated in the development of seed health testing techniques. Without the numerous contacts and fruitful co-operation (especially within the framework of the International Seed Testing Association and its Plant Disease Committee) in comparative testing schemes, international workshops, etc., I would not have been able to write this book.

Through these contacts I have received much valuable information, some of which has been acknowledged as 'personal communications'. Through the years I have been encouraged by many of my colleagues who have urged me to bring my book to completion. In this connection I cannot forget the late W. C. Moore, formerly director of the Phytopathological Laboratory of the Ministry of Agriculture, Fisheries and Food, at Harpenden, England, for his persistent stimulation.

In extending my thanks to the many colleagues who have helped me by checking the texts that fell within the realms of their specialities, I must first 
pay tribute to my closest colleague, Dr. Mary Noble, Department of Agriculture and Fisheries for Scotland, Edinburgh. Since the 1950s we have had the closest co-operation, and our joint efforts, together with other colleagues, in developing seed health testing techniques, and in formulating seed certification schemes and quarantine regulations, all advocate the incontestable principle that prevention is better than cure. Dr. Noble has read the whole book critically, and made numerous comments and suggestions. I can find no adequate expression for my gratitude to her for her careful perusal of the manuscript and for her inspiration and encouragement throughout the years in whatever I may have contributed to seed pathology.

The wide scope of the theme of this book has made consultation with specialists essential. I am grateful indeed for the prompt readiness of many outstanding colleagues for their valuable co-operation in reading chapters or sections of the book and for communicating their criticism and suggestions. I express my deep gratitude to the following for their co-operation: Dr. Joan Moore, Ministry of Agriculture, Fisheries and Food, London, who perused and gave most useful critical comments on Chapter 1 and the whole of Part III. Dr. H. C. Phatak, at present in Bangkok, Thailand, who checked Chapter 3. Professor Ernst Hellmers, Royal Veterinary and Agricultural University, Copenhagen, and Dr. D. C. Graham, Department of Agriculture and Fisheries for Scotland, Edinburgh, who checked Chapter 4. Dr. M. J. Thirumalachar, India, over a period associated with the Institute of Seed Pathology for Developing Countries, Copenhagen, who checked Chapter 5. Professor Clyde M. Christensen, University of Minnesota, U.S.A., who checked Chapter 7. Dr. Palle Krogh, Royal Veterinary and Agricultural University, Copenhagen, Denmark, and Dr. Chester Mirocha, University of Minnesota, U.S.A., who checked Chapter 8. Dr: Dalbir Singh, Reader, University of Rajasthan, India, who checked Chapter 10, Professor R. K. S. Wood, Imperial College, London, England, who checked Chapter 18. Dr. J. T. Mills, Canada Department of Agriculture, Winnipeg, Manitoba, who checked Chapters 21, 22 and 23. Dr. J. de Tempe, Government Seed Testing Station, Wageningen, the Netherlands, and Mr. R. B. Maude, National Vegetable Research Station, Warwickshire, England, who checked Table 22.3. Dr. Johs. Jørgensen, Danish Government Seed Testing Station, Copenhagen, who checked Chapter 24. Dr. S. B. Mathur, Institute of Seed Pathology for Developing Countries, Copenhagen, who checked Chapters 28 and 29. And finally, Professor Gaston Waringhien, Paris, for checking the Greek and Latin etymology of the terms included in the Glossary.

I have worked on this book for many years, but particularly intensively during the past eight years when I greatly needed texts for teaching seed pathology at the Institute of Seed Pathology in Copenhagen. I would like to thank my colleagues at the Institute for their interest and co-operation. 
The teaching and research activities at this Institute have given me a unique opportunity to study many details pertaining to routine testing for seed-borne pathogens. In these activities Dr. S. B. Mathur, my closest colleague through this period, has taken a most active part; his initiative and enthusiasm should be recorded here.

I have derived considerable benefit from the excellent technical assistance at the Institute in the preparation of the illustrations for the book, and I would like to thank Mrs. Olga Kongsdal for producing or redrawing many of the line drawings, and Mr. Magd El-din Ragab for his devoted and skilful co-operation in producing most of the original photographs.

My final thanks go to the excellent secretarial help I have received, and I am indebted to Mrs. Rigmor Hjælmhof for her patient copying of the thousands of items for the index. In the practical work on the manuscript I have received the greatest support and most efficient help from Mrs. Ellen Hersdorf. Her assistance in the typing of thousands of pages at all stages of the manuscript, and especially her efforts at reducing the 'stealing-in' of errors that is the ever-threatening spectre in the life of an author, have been invaluable. I wish to express my truly deep gratitude for her steady zeal in the elaboration and final accomplishment of this book.

The wide scope of the book, covering as it does a considerable range of aspects of plant pathology including the many categories of pathogens that may be transmitted through seeds, makes this work an ambitious one in the hand of one author. There are advantages and disadvantages of one-man authorship of a book of this type, which is always vulnerable to specialist criticism, and thus finally I wish to make a sincere request for critical comments and corrections. 


\section{Some suggestions on the use of the book}

There is a range of possibilities for the use of the book in university teaching. The texts to be included in a course depend, of course, on the scope of the particular course, and the time available.

Part I (Pathogens, Diseases, Hosts) which is the 'special' part is primarily a compendium of seed-borne pathogens and seed disorders, and also includes a review of their harmful effects on crop production and, in one chapter, on human and animal health. While the first eight chapters may be used mainly for reference, the last two chapters may be suitable for some courses, in particular Chapter 10 which deals with the fundamental subject of morphology and anatomy of seeds in relation to transmission of pathogens. This chapter at least should be included for graduate and postgraduate students. The introductory sections of some of the chapters may also be considered for inclusion.

Part II (Mechanisms of Seed Transmission) is considered as basic for any academic study of seed pathology. It outlines the 'natural laws' governing the establishment of pathogens in seeds, their transmission, and their further development in crops. I would suggest that in any comprehensive course at the graduate and post-graduate levels this part should be included as a whole, with some omissions. For courses at the undergraduate level I would certainly concentrate on Chapter 14, largely dealing with the major types of cycles of seed-borne diseases. It might be useful in these elementary courses also to include Chapter 11 describing the influence of environment on establishment of pathogens in the seed crop.

Part III (Control) can be used as a whole for graduate and post-graduate courses, with omissions according to the time available and the scope of the course. For undergraduate courses I would select Chapter 19 on seed crop management; also Section 20.1, the Conclusions of Section 20.2, and Chapter 21 dealing in a general way with seed treatment procedures and equipment.

Part IV (Testing Methods) should support courses in practical seed health testing at any level, and would provide texts for thorough studies at the graduate and post-graduate levels.

Part V (Assessment of Seed-borne Inoculum) is, I think, truly basic for any interpretation of results recorded in seed health testing, and funda- 
Table 0.1 Summary of suggested sections of the book to be included in university and other courses

\begin{tabular}{|c|c|c|c|c|}
\hline Part & Undergraduate & Graduate & Post-graduate & Technicians \\
\hline $\begin{array}{l}\text { I } \\
\text { Pathogens, } \\
\text { Diseases, Hosts } \\
(1-10)\end{array}$ & None & $\begin{array}{l}\text { Sections } 1.3 \text {, } \\
3.1-3.4 \text {. Intro- } \\
\text { duction to } \\
\text { Chapter } 4 . \\
\text { Sections } 4.1 \text {, } \\
5.1,5.2 \text { Intro- } \\
\text { duction to } \\
\text { Chapter } 6 . \\
\text { Chapter } 10\end{array}$ & $\begin{array}{l}\text { As for Graduate, } \\
\text { plus Chapter } 7\end{array}$ & $\begin{array}{l}\text { Subsections of } \\
\text { Chapter } 2\end{array}$ \\
\hline $\begin{array}{l}\text { II } \\
\text { Mechanisms of } \\
\text { Seed } \\
\text { Transmission } \\
(11-18)\end{array}$ & $\begin{array}{l}\text { Chapters } 11 \text { and } \\
14\end{array}$ & All chapters & All chapters & $\begin{array}{l}\text { Chapters } 13 \text { and } \\
14 \text {, with some } \\
\text { omissions }\end{array}$ \\
\hline $\begin{array}{l}\text { III } \\
\text { Control } \\
(19-24)\end{array}$ & $\begin{array}{l}\text { Introduction. } \\
\text { Chapters } 19 \text { and } \\
21, \text { Sections } \\
20.122 .3,22.6 \\
22.10 \text { and } 24.1\end{array}$ & $\begin{array}{l}\text { Introduction. } \\
\text { Chapters } 19, \\
21-24, \text { and Sec- } \\
\text { tion } 20.1 \text { and } \\
\text { Subsection } 20.2 .6\end{array}$ & $\begin{array}{l}\text { Introduction and } \\
\text { all chapters }\end{array}$ & $\begin{array}{l}\text { Chapter 23, with } \\
\text { some omissions }\end{array}$ \\
\hline $\begin{array}{l}\text { IV } \\
\text { Testing Methods } \\
(25-31)\end{array}$ & $\begin{array}{l}\text { Chapters } 25-28 \\
\text { for reference; } \\
\text { Sections } 31.2 \\
\text { and } 31.3\end{array}$ & All chapters & All chapters & Chapters $25-30$ \\
\hline $\begin{array}{l}\text { V } \\
\text { Assessment of } \\
\text { Seed-borne } \\
\text { Inoculum } \\
\text { (32) }\end{array}$ & None & Chapter 32 & Chapter 32 & None \\
\hline
\end{tabular}

mental for the establishment of rational disease tolerances in seed certification schemes. This part, I believe, should be included in any course at the graduate and post-graduate levels.

The book may also be used in courses for training technicians in seed health testing. For such purposes, I suggest the selection of Chapter 2 on diseases and injuries of seed (with omissions), and most of Chapter 13 dealing with modes of infection and contamination of seed; the essential sections of Chapter 14, discussing disease cycles, should perhaps also be taught to convey a general understanding of seed-borne diseases. Important in courses for technicians would be the whole of Part IV, dealing with methods of testing (with omission of some special discussions), and possibly also Chapter 23 , on testing of seed germicides and treated seed, with some omissions.

I have summarised these suggestions in Table 0.1 


\section{List of Colour Plates}

(appearing between pages 232/233 and 680/681

Plates I and II. Habit characters of Fusarium on seeds after 7 days of incubation in the blotter test.

Plate III. Colour infrared aerial photograph showing bean fields near Hensall, Ontario, infected with bacterial blight.

Plate IV. Top left - soybean seed with mottling of seed coat, due to infection of mother plants by soybean mosaic virus; top right - seed rot and discoloration in maize seeds due to Diplodia maydis. Middle left rice seed with discoloration due to Drechslera oryzae and Trichoconis padwickii; middle right - soybean seed with discoloration caused by Cercospora kikuchii. Bottom - agar plate test on oxgall-potato dextrose agar, showing different species of Fusarium.

Plate V. Aerial photograph of a field of white beans near Hensall, Ontario, infected with bean blight, Xanthomonas phaseoli. 


\section{Seed Pathology}

\section{VOLUME II}




\section{Seed Pathology}

\section{VOLUME II}

\section{PAUL NEERGAARD}

Director, Danish Government Institute of Seed Pathology for Developing Countries, Copenhagen, Denmark

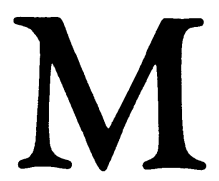




\section{CONTENTS OF VOLUME II}

$\begin{array}{ll}\text { Glossary } & \mathbf{8 4 1}\end{array}$

$\begin{array}{lr}\text { References } & 879\end{array}$

$\begin{array}{ll}\text { Index } & 1021\end{array}$

\section{Summary of Contents of Volume I}

\section{PART I PATHOGENS - DISEASES - HOSTS}

1. Economic Significance of Seed-borne Diseases

2. Diseases and Injuries of Seed

3. Seed-borne Viruses

4. Seed-borne Bacteria

5. Seed-borne Fungi

6. Seed-borne Nematodes

7. Storage Fungi

8. Impact of Seed-borne and Storage Fungi on Animal and Human Health

9. Types of Host in Relation to Types of Pathogen

10. Morphology and Anatomy of Seeds in Relation to Transmission of Pathogens 


\section{PART II MECHANISMS OF SEED TRANSMISSION}

Introduction to Part II

11. Environment and Plant-Seed Transmission

12. Entry Points of Seed Infection

13. Infected or Contaminated Parts of the Seed

14. Seed-Plant Transmission, Establishment of Infection and Course of Disease

15. Environmental Physicochemical Factors Affecting Establishment and Course of Disease

16. Environmental Biotic Factors Affecting Establishment and Course of Disease

Intermezzo: Integration of Disease Disposing Factors

17. Factors Inherent in the Pathogen Affecting Establishment and Course of Disease

18. Factors Inherent in the Host Affecting Establishment and Course of Disease

\section{PART III PRINCIPLES OF CONTROL}

Introduction to Part III

19. Seed Crop Management

20. Management of Seed Storage

21. Seed Treatment, Procedures and Equipment

22. Mechanism and Practical Use of Chemical Seed Treatment

23. Testing Seed Germicides and Treated Seed 
Summary of Contents of Volume I

24. Quarantine for Seed

\section{PART IV SEED HEALTH TESTING METHODS}

25. Objectives of Seed Health Tests

26. Sampling

27. Examination of Ungerminated Seed

28. Incubation Tests I: Procedures

29. Incubation Tests II: Factors Affecting Test Results

30. Bioassays and Biochemical Procedures

31. Inspection of Plants beyond the Seedling Stage

\section{PART V ASSESSMENT OF SEED-BORNE INOCULUM}

32. Forecasting Losses from Seed-borne Diseases and Assessing Disease Tolerances for Seed Health Testing 